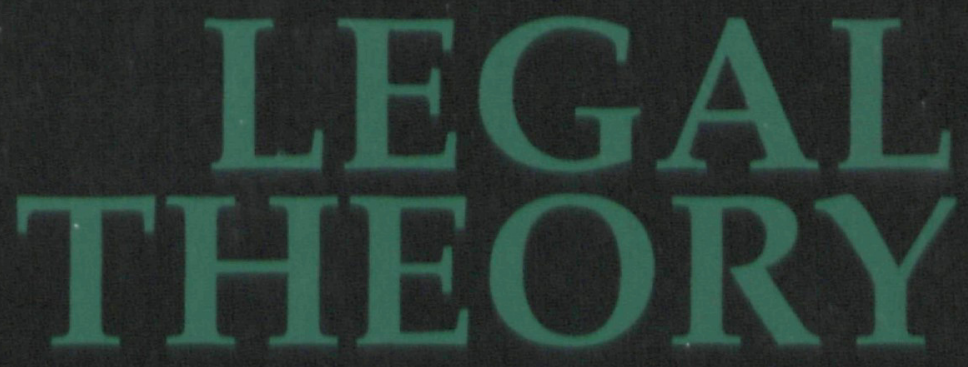

\title{
Volume 1 \\ Number 2
}

\section{June 1995}

\section{CAMBRIDGe} UNIVERSITY PRESS 


\section{EDITORS}

Larry Alexander, University of San Diego School of Law

Jules L. Coleman, Yale Law School

Frederick Schauer, Harvard University, John F. Kennedy School of Government

\section{EDITORIAL BOARD}

Bruce Ackerman, Jale University

Robert Alexy, University of Kiel

Anita Allen, Geongetown University

Lea Brilmayer, New York University

Ruth Chang. University of Califomia, Los Angeles

Robert Cooter, University of California, Benkely

Richard Crasivell, University of Southem Califomia

Meir Dan-Cohen, University of California, Berkeley

Antony Duff, Stirling University

Gerald Dworkin, University of Jllinois, Chicago

Ronald Dworkin, New Yoik University; Oxford

University

Robert Ellickson, Yale Law Schiool

Joel Feinberg, University of Arizona

John Finnis, Oxfond University

Ruth Gavison, Helnnu University

Kent Greenawalt, Columbia University

Thomas Grey, Stanford University

Michael Hechter, University of A rizona

Douglas Heckathorn, Univensity of Connecticut

Risto Hilpinen, Tuku University

Heidi Hurd, Universily of Pennsilvania

Frances Kamm, New York Universily

Louis Kaplow, Harvand University

Mark Kelman, Stanford Universily

Lewis Kornhauser, New Yoik Univensily

Jody Kraus, University of Vinginia

Brian Leiter, Rutgens Univensity
Saul Levmore, University of Vinginia

David Lyons, Comell University

Neil MacCormick, Edinburgh University

Andrei Marmor, University of

TelAviv

Frank Michelman, Harvard University

Michael Moore, University of Pennsyluania

Stephen Munzer, University of California, Los Angeles

Jefrrie Alurphy, Arizona State University

Stephen Perry, McGill University

Gerald Postema, University of North Carolina

Margaret Jane Radin, Stanford University

Joseph Raz, Oxford University

Donald Regan, University of Michigan

Janet Radcliffe Richards, The Open University, UK

Carol Rose, Yale University

Roger Shiner, University of Alberta

Walter Sinnott-Armstrong, Dartmouth College

Patricia Smith, University of Kentucky

Cass Sunstein, University of Chicago

Csaba Varga, Budapest University

Jeremy Waldron, University of Califomia

Steven Walt, University of Vinginia

Wil Waluchow, MfeMlasler University

Richard Wasserstrom, University of Califomia,

Santa Cour

Alan Wertheimer, University of Vermont

Robin West, Geongetown University

Edltorlal Ornce: Irgal Theory. Yale Law School, Draver 401A Yale Station, New Haven, Connecticut 06520, USA; Fax: $203-492-8260$.

Publishing, Subscription, and Advertising Offices: Cambridge University Press, 40 West 20th Street, New York NY 10011; or Cambridge University Press, The Edinburgh Building, Shaftesbury Road, Cambridge CB2 2RU, England.

Legl Theory is published quarierl): Annual subseription rates for Volume 1. 1995: Institutions: $\$ 100.00$ in the USA, Canada, and Mexico; UKf62.00 in all other countries. Individuals: $\$ 50.00$ in the USA, Canada, and Mexico; UKf $\$ 1.00$ in all other countries. Prices include postage and insurance; airmail outside the USA, Canada, and Afexico is $\$ 20.00$ extra.

Copjright 01995 Cambridge Univering Press. All rights reserved. No part of this publication may be reproduced, in any form or by any means, electronic, photocopying or otherwise, withou: permission from Cambridge University Press. Pliotocopying information for users in the USA: The Item-Fee Cele for this publication (1952-3252/95 $\$ 7.50$ $+.10)$ indicates that copying for internal or personal use bejond that periuitted by Sec. 107 or 108 of the US Copyright Law is authorized for users duly registered with the Copjright Clearance Center (CCC) Transaction Reporting Service, provided that the appropriate remittance of $\$ 7.50$ per article is paid directly to: CCC, 222 Rosewood Drive, Danvers, MA 01923. Specilic written permission must be obtained from Cambridge University Press for all other copjing. Contact the ISI Tearsheet Service, 3501 Market Street. Philadelphia, PA 19104, for single copies of separate articles.

Second-class postage paid at New York, NY, and additional mailing ofrices. Forwarding and Return Postage Guaranteed. Address Correction Requested. Postmaster: Send address clianges in the USA and Canada to: Legal Throry. Cambridge University Press, Journals Fulfillment Dept., 110 Midland Ave., Port Chester, NY $10573-4930$.

Printed in the United States of America. 